\title{
結晶格子と走査型トンネル顕微鏡を用いた 原子トラッキング制御の高安定化*
}

一 原子エンコーダの検証 —

\author{
外川陽一** Pongpun Rerkkumsup ${ }^{* *}$ 本田 裕 ${ }^{* *}$ 明田川正人 高田孝次 $^{\dagger \dagger}$
}

Highly stable atom-tacking control of using regular crystalline lattice and scanning tunneling microscope
- Validation of Atomic Encoder-

Yoichi TOGAWA, Pongpun RERKKUMSUP, Hiroshi HONDA, Masato AKETAGAWA and Koji TAKADA

In this article, we propose a technique for highly stabilized atom-tracking control of a scanning tunneling microscope (STM) tip by referring to an atomic point (or atomic array) on a regular crystalline surface. Graphite crystal, whose lattice spacing is approximately $0.25 \mathrm{~nm}$, was utilized as the reference. To enhance stability of the atom-tracking control against external disturbances, a new atom-tracking controller, which consists of integrator, tracer and limiter units, was developed. The integrator unit is designed to eliminate the steady-state error due to thermal drift. A phase-lag low-pass filter is utilized as the tracer unit to compensate the disturbance due to vibration/acoustic noise. To improve the phase margin of the controller, the limiter unit consists of a phase-lead high-pass filter and a saturator whose output is less than one-half of the lattice spacing. The performance of the stabilized technique, which is to combine the new tracking controller with enhanced STM stiffness, was evaluated using internal/external artificial disturbance generators. The experimental results show that the proposed method has a high capability for maintaining atom-tracking control without any jumping of the STM tip to neighboring atoms, even in a noisy environment. The method was also applied to atom-stepping control of the STM tip by referring to some crystalline axis. The atom-stepping control atom by atom along the crystalline axis over a range of 200 atoms, at a rate of 10 atoms/sec, was performed without missing the atomic array.

Key words: scanning tunneling microscope (STM), atom-tracking, regular crystalline lattice, disturbance, atomic encoder

\section{1. 序論}

ナノテクノロジの急速な進展に伴い, サブnmオーダ精度をも 位置決め法の開発が求められている。従来より, この用途に はレーザ干渉測長機が用いられているが，波長以下の変位を決め る位相補間にnmオーダの誤差が混入し ${ }^{1)}$, サブnm精度の位置決 めは困難であると考えられる．結晶格子の格子間隔はおよそ 0.2 nmであり，結晶自体が無応力で格子欠陥がなければ，これは長 期にわたって安定し，これを基準とする位置決め法が可能と考え られる．例えば格子間隔毎にステージ等を連続ステップ移動さ せ，格子間隔を基準として変位を検出する技術（本報ではこれを 原子エンコーダと定義する）があれば, ナノメートル領域での位 置決め (測長) に多いに貢献すると考えられる. シリコンの格子 間隔を測定するX線干渉計では，この技術が開発されている2). しかしX線干渉計は装置が特殊であり, 充分なコントラストを 一定に保つ調整が微妙な為, 産業界では一般に利用されていな い. 走査型トンネル顕微鏡（Scanning Tunneling Microscope : STM $)^{3)}$ は，原子まで捉える高分解能性，簡便性から表面技術の 分野で浸透している．結晶格子をスケールに，STMを検出器と して組み合わせれば，結晶格子を基準とする位置決め法（ある いは変位検出法）を開発できる可能性がある ${ }^{4), 5)}$. STM探針を

\footnotetext{
* 原稿受付 平成16年3月 25 日

** 学生会員 長岡技術科学大学大学院

$\dagger$ 正会 員 長岡技術科学大学（新潟県長岡市上富岡町 1603-1）

†† 正会員 長岡工業高等専門学校 (新潟県長岡市西片貝町888)
}

高速で微小円運動（ディザ振動）させてトンネル電流を変調し， この変調信号と同期した参照信号をロックインアンプにより同 期検波（ロックイン検出）することで試料表面の凹凸情報（=2 次元の傾斜信号) が得られる ${ }^{6}$. ディザ振幅を格子間隔以下とし たとき，傾斜信号がゼロになる点は原子頂点（又は底点）となる ので，これらをゼロとするようにSTM探針（又は試料）の位置 を制御すれば，STM探針を常に原子頂点に位置決めできる ${ }^{7) ~ 9) ~}$ (本報では，これを原子トラッキング制御と呼ぶ)。これを利用 し，STM探針を格子配列上の隣り合う原子頂点へステップ移動 させる位置決め（=原子エンコーダ） が開発可能と考えている. しかし原子トラッキングは振動, 音響, 熱ドリフトなどの外乱 に対する安定性が低く，例えば外乱の多い昼間の環境下では長 時間安定した制御を達成することが困難である．原子エンコー ダを実用化する為には，外乱に対して，よりロバストな原子卜 ラッキング制御が必須である.

以上の背景を基に，本報では以下の検討を行った。

（1）外乱ノイズの調査を行い，その結果を基に，外乱に対して ロバストなトラッキングコントローラを設計した.

(2) 外乱発生器をSTMに組み込み, 原子トラッキング制御の安 定性を評価した。

(3) 新たに設計したトラッキングコントローラを利用して, 格 子配列に沿ったSTM探針の原子ステップ移動を行った. 


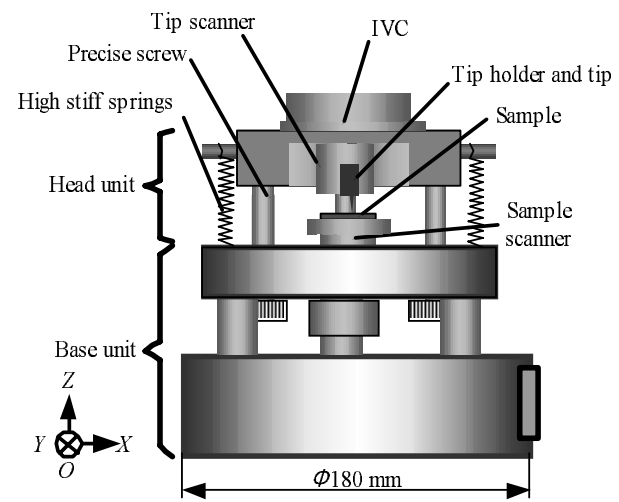

Fig. 1 A schematic of an STM used in experiments. A tubetype $X Y Z$ PZT actuator is used as a sample scanner for $X Y$ raster scanning, atom-tracking and $Z$-servo operation. The tube-type $X Y$ PZT actuator is used as a tip scanner for dither modulation

Table 1 Stiffness and resonant frequencies of the STM head (4 springs / 2 springs) and environmental conditions

\begin{tabular}{l|l|l}
\hline \multirow{2}{*}{ Stiffness } & Vertical & $5.3 / 2.8 \mathrm{~N} / \mu \mathrm{m}$ \\
& Horizontal & $3.9 / 2.4 \mathrm{~N} / \mu \mathrm{m}$ \\
\hline \multirow{2}{*}{ Resonant freq. } & Vertical & $471 / 320 \mathrm{~Hz}$ \\
& Horizontal & $402 / 340 \mathrm{~Hz}$ \\
\hline \multirow{4}{*}{ Thermo- } & Sound reduction & $-10 \mathrm{~dB}$ \\
\cline { 2 - 3 } stabilized cell & Sound level & Nighttime 40-45 dB \\
& (typical, inside) & Daytime 70-75 dB \\
\cline { 2 - 3 } & Temperature stability & $\pm 0.05 \mathrm{~K}$ \\
\hline Thermal drift & Rate (typical) & $10-50 \mathrm{~nm} / \mathrm{h}$ \\
\hline Vibration- & Resonant frequency & $2 \mathrm{~Hz}$ \\
isolation table & & \\
\hline
\end{tabular}

\section{2. 走査型トンネル顕微鏡の構成と外乱ノイズの調査}

\section{1 走査型トンネル顕微鏡の構成}

図1に実験で使用したSTMの概略図を示す，STMは，電流電 圧変換器 (IVC) と探針用 $X Y$ 軸チューブスキャナからなるへッ ド部と, 試料用 $X Y Z$ 軸チューブスキャナを組み込んだベース部 からなる. STMを構成する部材はスーパーインバール（線膨張 率 $\left.0.5 \times 10^{-6} / \mathrm{K}\right)$ で製作されている. 探針スキャナはディザ振 動に, サンプルスキャナは原子トラッキング制御と $Z$ 方向の制 御に用いた。観察試料にはグラファイト結晶 (Highly oriented pyrolytic graphite : HOPG）を用いた. ヘッド部はベース部にば ね（ばね定数 $10 \mathrm{~N} / \mathrm{m} ）$ で固定されている. 実験では 2 種のばね を用いた，STM本体は恒温セル ${ }^{10)}$ の中に入れ，さらにそれらを 除振台（共振周波数 $2 \mathrm{~Hz}$ ）に設置した. 装置剛性と環境条件を 表1に示す.

\section{2 外乱ノイズの調査}

振動や音響, 熱ドリフトなどの外乱が原子トラッキング制御 に大きな影響を及ぼす，外乱の多い昼間の環境下では，探針が 制御中, 次々に他の原子に移動し, 安定した制御を長時間行うこ とが困難である. この原因を探る為, 外乱の周波数成分をラス 夕走査を行わないときのトンネル電流のスペクトラムから調査 した.このとき, 外乱がなければZサーボによりトンネル電流は

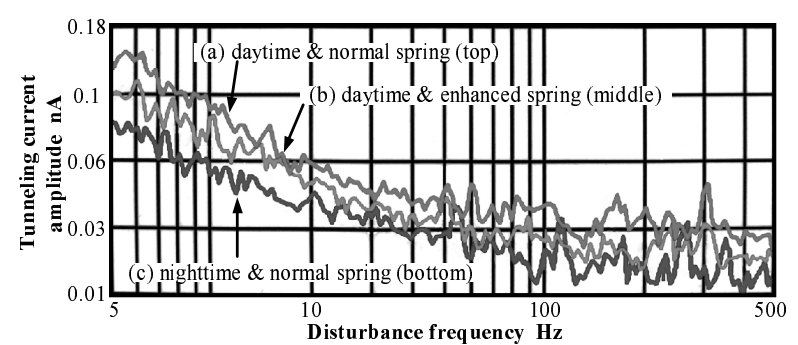

Fig. 2 The effects of external disturbance on the spectrum of the tunneling current without $X Y$ raster scanning. The top (a), middle (b), and bottom (c) power spectra are for a normal-stiffness STM in daytime, enhanced-stiffness STM in daytime, and normal-stiffness STM in nighttime environments, respectively

一定となるはずである．外乱がトンネル電流に混入すれば，そ のスペクトラムから外乱の周波数特性が判る. I/Vコンバータの 出力を，(1)昼間／岡性を強化しない，(2)昼間／岡性を強化，(3) 夜間 / 剛性を強化しない，の3個の条件下でFFTアナライザを用 いて調査した。このとき, トンネル電流の目標值は $2 \mathrm{nA}$ (バイ アス電圧 $=50 \mathrm{mV}$ ）とした. FFTの平均化を3分間行った結果を 図2に示す，同図(a)，(b)，(c)はそれぞれ，昼間/岡性を強化しな い, 昼間/岡性を強化, 夜間/岡性を強化しないの場合の結果を示 す. 図2より以下の事が判る。

（1）昼間は夜間より外乱成分が多い. 特に $100 \mathrm{~Hz}$ 以下が多い.

（2）へッド固定のばねを強化すると剛性の向上に伴い外乱によ るトンネル電流のノイズは減少する. 特に $100 \mathrm{~Hz}$ 以上では 夜間とほぼ同等である.

3者間で $100 \mathrm{~Hz}$ 以上でも差は見られるが, $10 \mathrm{pA}$ 程度の領域で あり，100 Hz以下を外乱の主成分とした．また $200 \mathrm{~Hz}$ 以上はほ ぼホワイトノイズであった，我々のシステムでは，傾斜信号を 検出するロックインアンプの帯域が $160 \mathrm{~Hz}$ (-3 dB落ち) であ るので，160 Hz以下の外乱はコントローラで補償し，160 Hz以 上は剛性の強化で抑制することで原子トラッキングの安定化を 図った.

\section{3. 原子トラッキング制御安定条件とコントローラの設計}

\section{1 原子トラッキング制御安定条件}

図3(a)に原子トラッキング制御システムの概略図，(b)に同図 (a)を簡略化した制御系のブロック線図を示す. 同図(b)に示され る $A_{c}(t), A_{d}(t)$ はそれぞれサンプルスキャナに印加される位置 制御量, 外乱変位と定義する. 制御中, STM探針が目標となる 原子を見失うことなく原子トラッキングを達成するためには, 次 式を満たす必要がある.

$$
\left|A_{d}(t)-A_{c}(t)\right| \leq k d
$$

ここで， $k$ は定数で $0 \leq k \leq 1 / 2 ， d$ は格子間隔を示す. 式 $(\mathbf{1})$ は, 位置制御量と外乱変位の偏差が格子間隔の半分以下なら, STM探針が他の原子に移動しないことを意味する．また外乱は， A) 熱ドリフトなどのランプ的な変位外乱，B) 音響・振動など の周期的な正弦波状の変位外乱の 2 種類に大きく分けられ，これ らはコントローラでそれぞれ補償されなければならない，以下， 

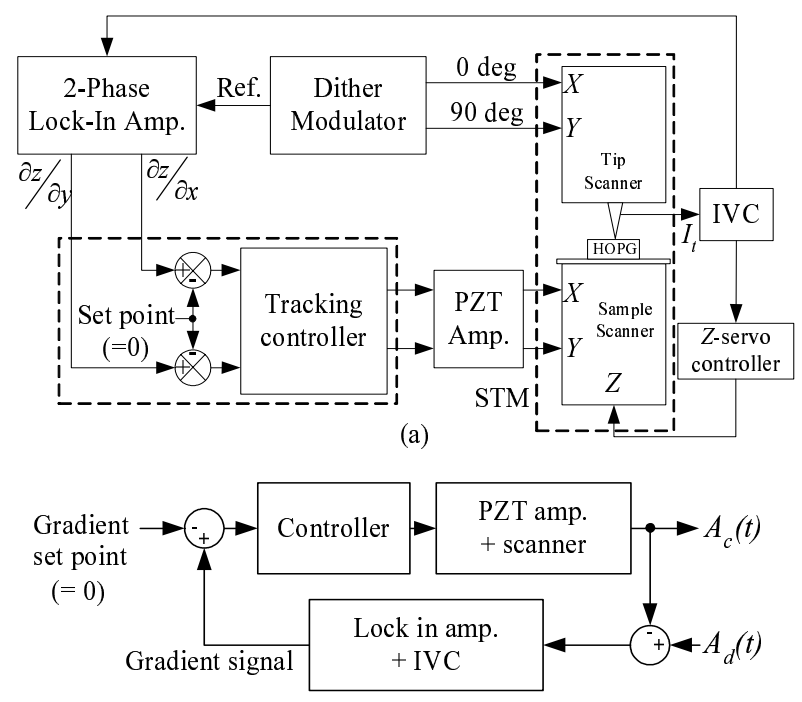

(b)

Fig. 3 (a) is a schematic block diagram of an atom-tracking system. (b) is a simplified control block diagram of the closed-loop atom-tracking system. $A_{c}(t)$ and $A_{d}(t)$ are control signal and disturbance displacement, respectively

式（1）を基にして熱ドリフトと音響・振動変位それぞれに対す る補償条件を述べる。

\section{2 熱ドリフト補償条件}

熱ドリフトは，熱変形による探針-試料間の相対変位であり， 測定時間と熱ドリフト速度の積と考えることができ，ランプ状の 変位外乱として扱ってよい. 従って, 次式のように与えられる.

$$
A_{d}(t)=k_{t h} t
$$

ここで, $A_{d}(t)$ は熱ドリフト量, $k_{t h}$ は熱ドリフト速度を示す. 熱ドリフト量 $A_{d}(t)$ と探針（又は試料）の位置制御量 $A_{c}(t)$ との 間の定常偏差 $e_{s s}$ が格子間隔の半分以下なら, STM探針が他の原 子に移動することなく制御が達成される. 従って, 式 (1) と式 （2）から，次式を満たせば良い.

$$
\begin{aligned}
\left|e_{s s}\right| & =\lim _{t \rightarrow \infty}\left|A_{d}(t)-A_{c}(t)\right| \\
& =\lim _{t \rightarrow \infty}\left|k_{t h} t-A_{c}(t)\right| \leq k d
\end{aligned}
$$

定常偏差は積分器で補償することができ, 式 (3) を用いて, 後 に示すコントローラの積分ゲインを決定できる.

\section{3 音響・振動外乱補償条件}

音響・振動外乱は周期的な正弦波状の変位と考えられる, そ こで, 外乱による変位を $A_{d} \cos (\omega t)$, 制御量を $A_{c} \cos \left(\omega t-\phi_{c}\right)$ とおく.ここで, $A_{d}, A_{c}, \phi_{c}, \omega$ はそれぞれ，音響・振動の外 乱振幅, 位置制御量の振幅, 制御信号の位相遅れ, 角周波数を示 す. 外乱変位 $A_{d} \cos (\omega t)$, 位置制御量 $A_{c} \cos \left(\omega t-\phi_{c}\right)$ を式 (1) 中の $A_{d}(t), A_{c}(t)$ と置き換えると, 制御中STM探針が隣りの原 子一移動することなく原子トラッキングを達成する為には, 次 式が成立する必要がある。

$$
\begin{aligned}
& \left|A_{d} \cos (\omega t)-A_{c} \cos \left(\omega t-\phi_{c}\right)\right| \\
& =\left|\sqrt{A_{d}^{2}-2 A_{d} A_{c} \cos \left(\phi_{c}\right)+A_{d}^{2}} \cos \left(\omega t-\phi_{c}\right)\right| \leq k d
\end{aligned}
$$

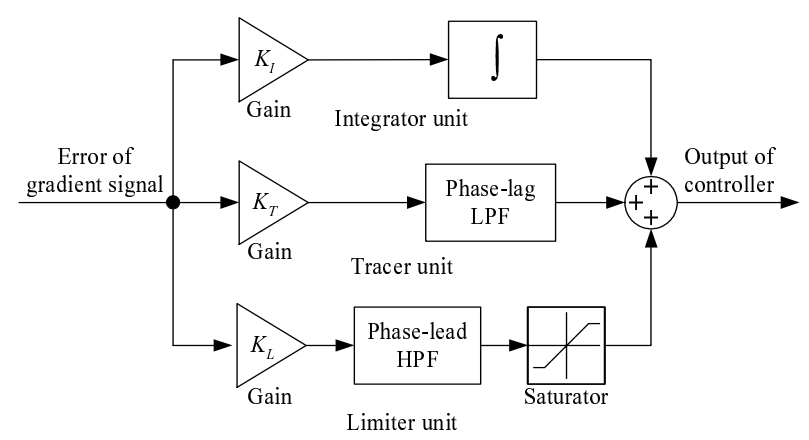

Fig. 4 A schematic block diagram of the newly proposed controller. The controller consists of integrator, tracer (Phaselag low-pass filter) and limiter (Phase-lead high-pass filter + Saturator) units

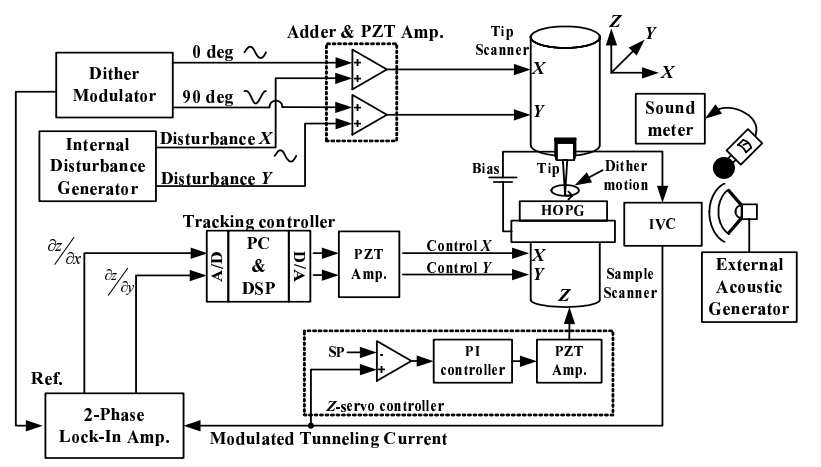

Fig. 5 The experimental system used to evaluate the performance and the robustness of the new stabilization technique

これはさらに次式のように書き換えることができる.

$$
1-2 \frac{A_{c}}{A_{d}} \cos (\phi)+\left(\frac{A_{c}}{A_{d}}\right)^{2} \leq \frac{k^{2} d^{2}}{A_{d}^{2}}
$$

$\left|A_{c} / A_{d}\right|$ とその位相遅れ 伝達関数で決定できるので, 外乱振幅 $A_{d}(\omega)$ が決まれば, 式 (5) を用いて制御振幅 $A_{c}(\omega)$ を評価できる. このシミュレーション 結果は後に述べる.

\section{4 トラッキングコントローラの設計}

以前まで原子トラッキング制御のコントローラとして経験的 に調整したPI (Proportional - Integral）コントローラを用いて いたが9), 昼間の環境下で長時間安定した制御を達成することは 困難であった．外乱ノイズの調査から得た安定化の指針を基に， 熱ドリフトと音響・振動をそれぞれ補償するコントローラを設 計した．新たに設計したトラッキングコントローラのブロック 図を図4に示す，トラッキングコントローラはインテグレータ部 $\left(\right.$ ゲイン $\left.K_{I}\right)$, トレーサ部 (ゲイン $\left.K_{T}\right)$, リミッタ部（ゲイン $\left.K_{L}\right)$ からなる. インテグレータ部には熱ドリフトなどのランプ 状外乱変位による定常偏差を除去する為に積分器を用いた. ロッ クインアンプのカットオフ周波数 $(160 \mathrm{~Hz})$ 以下の音響・振動 外乱を補償し, かつ高周波外乱をカットオフする為, トレーサ 部には帯域が調整可能な位相遅れ補償器 (Phase-Lag Low-Pass Filter：LPF）を用いた. $160 \mathrm{~Hz}$ での位相遅れを改善するため, リミッタ部には位相進み補償器（Phase-Lead High-Pass Filter： 
Table 2 Experimental conditions of the tracking system

\begin{tabular}{l|l|l}
\hline \multirow{4}{*}{ STM } & Sample & Graphite (HOPG) \\
\cline { 2 - 3 } & Tip & $\phi 0.25 \mathrm{~mm}, \mathrm{Pt}-\mathrm{Ir}$ \\
\cline { 2 - 3 } & Bias voltage & $50 \mathrm{mV}$ \\
\cline { 2 - 3 } & Set-point current & $2 \mathrm{nA}$ \\
\cline { 2 - 3 } & $\begin{array}{l}\text { Sample scanner } \\
\text { sensitivity }\end{array}$ & $7.8 \mathrm{~nm} / \mathrm{V}$ \\
\cline { 2 - 3 } & $\begin{array}{l}\text { Tip scanner } \\
\text { sensitivity }\end{array}$ & $5.6 \mathrm{~nm} / \mathrm{V}$ \\
\hline \multirow{4}{*}{$\begin{array}{l}\text { Lither } \\
\text { amplifier }\end{array}$} & Amplitude & $\fallingdotseq 0.01 \mathrm{~nm}$ \\
\cline { 2 - 3 } & Frequency & $10 \mathrm{kHz}$ \\
\hline DSP (AD/DA) & $\begin{array}{l}\text { Input } \\
\text { amplification }\end{array}$ & $\times 10$ \\
\cline { 2 - 3 } & Cut-off freq. (-3 dB) & $160 \mathrm{~Hz}$ \\
\cline { 2 - 3 } & Slope & $-20 \mathrm{~dB} /$ decade \\
\hline
\end{tabular}

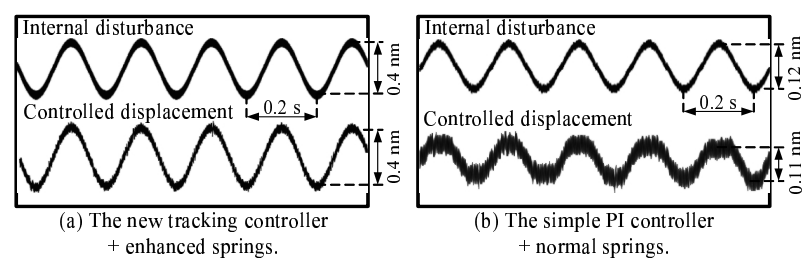

Fig. 6 Experimental results of the performance assessments for (a) the new controller + enhanced springs and (b) the PI controller + normal springs. The upper and lower signals are the internal artificial disturbance and the controlled displacement, respectively.The displacement is determined using the sensitivity of the sample scannrer and the $X$ controll signal applied to the sample scanner

HPF）を用い，HPFを通過する高周波ノイズを飽和器で格子間 隔の半分以下に制限する。

実際の実験では，それぞれのゲインを以下のように決定した。

（1）ゲイン $K_{I}(=0.05 ）$ は，そのときの熱ドリフト量（典型值 $10 \mathrm{~nm} / \mathrm{h}$ ) を基に式（3）を用いて計算・調整した.

(2) ゲイン $K_{T}(=0.005)$ は, 閉ループ伝達関数が $\left|A_{c}(\omega) / A_{d}(\omega)\right|=0.9$ となるように，式（5）を用 いて調整した.

（3）ゲイン $K_{L}\left(=0.035 ）\right.$ は， $160 \mathrm{~Hz}$ での位相遅れが $30^{\circ}$ 以内 になるよう調整した。

\section{4. 原子トラッキング制御安定性評価実験}

外乱発振器をSTMに直接挿入し, 提案したトラッキングコン トローラを以前調整したPIコントローラと比較・評価した。図5 に原子トラッキング制御安定性評価の実験システムを示す。実 験システムは，2つのチューブスキャナからなるSTM，I/Vコン バータ，ロックインアンプ (NF回路社，5610B)，STMコント ローラ（デジタルインスツルメンツ社, NanoscopeIII), トラッ キングコントローラ（DSP + 16 bit AD/DA，システムデザイン サービス), 外乱発振器, ディザ発振器から構成される. 音響) イズに対する安定性を評価する為，除振台とは切り離した台に スピーカを設置した。サンプルスキャナで原子トラッキング制 御とZ方向の制御を行う。探針スキャナはディザ振動に利用する

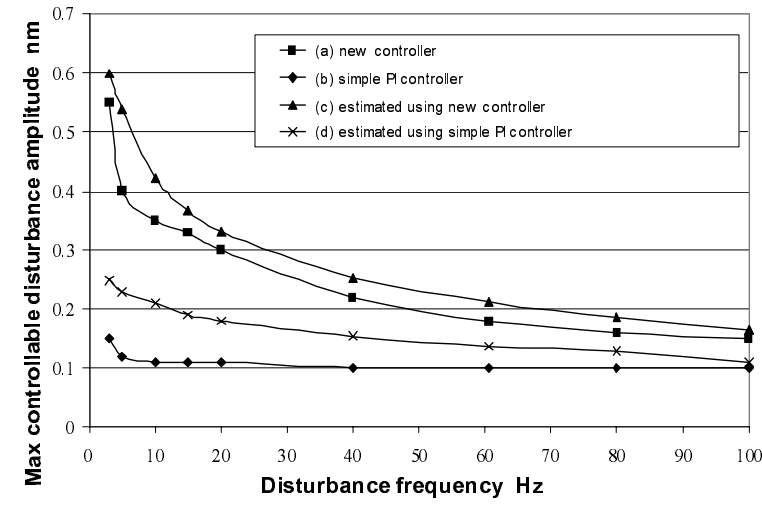

Fig. 7 A relationship between the maximum controllable disturbance amplitude and the frequency for the artificial internal disturbance

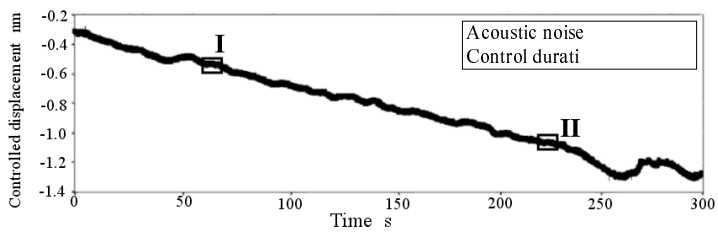

(a)

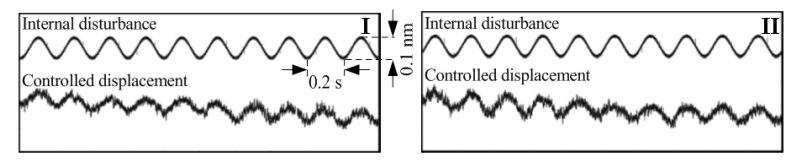

(b)

(c)

Fig. 8 (a) A part of the long atom-tracking control against disturbances in daytime. (b) and (c) Expanded images of I/II portions shown in (a), and the relationship between the internal disturbance and controlled displacement

と共に，人工的な外乱信号を直接混入させる. 実験手順を以下 に述べる.

（1）コントローラを介して $X Y$ 方向の傾斜信号をサンプルスキャ ナにフィードバックし，特定の原子頂点にSTM探針を静止 させる原子トラッキング制御を行う。

（2）原子トラッキング制御中，探針スキャナの $X$ 方向に，音響・ 振動の周期的な外乱変位を想定し，正弦波信号を印加寸る.

（3）外乱信号とX方向の制御信号を同時に観察する.このとき, 制御信号が外乱信号に対して同期かつ安定し，ある評価時 間以上STM探針が隣りの原子一移動しなければ，制御は成 功したと判定する. 隣りの原子への移動は制御信号と傾斜 信号の変化から判定できる（ここで評価時間は1分とした）.

外乱信号をある周波数に固定した状態でその振幅を増加して いき，制御可能な振幅を調查した．実験は，(1)新トラッキング コントローラ/岡性を強化したSTM (バネを4本)，(2) PIコント ローラ/ 剛性を強化しないSTM (バネを2本)，2通りの条件で 行った。

安定性評価実験は外乱の少ない夜間に行った，実験条件を表 2に，実験結果を図6に示寸，同図(a)は新しいトラッキングコン 


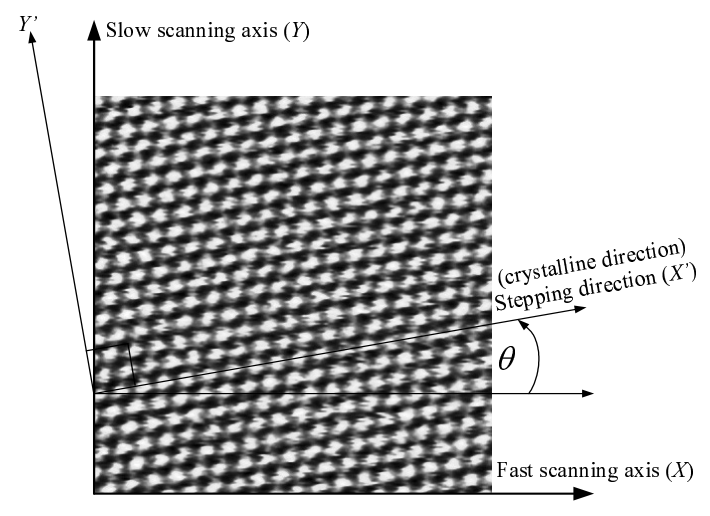

Fig. 9 STM image of graphite crystal surface. $X$ and $Y$ are the scanning axes of the sample scanner. $X^{\prime}$ and $Y^{\prime}$, respectively, are the axes parallel and normal to the crystalline axis. $\theta$ is the angle between the $X$ and $X^{\prime}$ axes

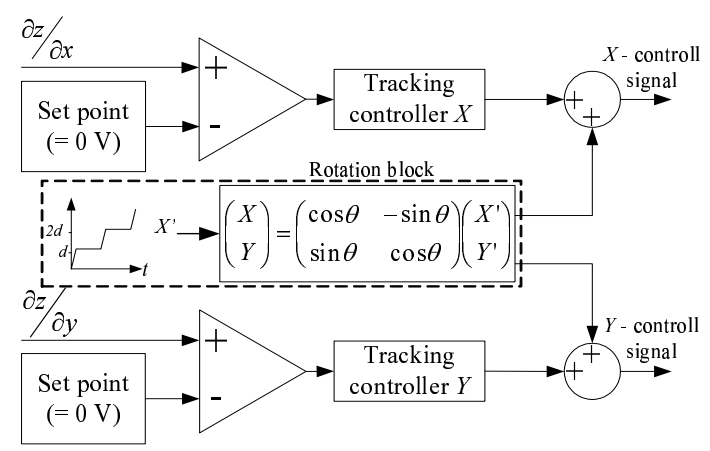

Fig. 10 Schematic block diagram of the atom-tracking and stepping control by referring to atomic arrays in the direction $\theta$

トローラ，右側(b)はPIコントローラの結果を示し，それぞれの 図で上の信号と下の信号は，外乱信号と制御信号を示す．PIコ ントローラのP覀ン $(=0.007)$, Iゲイン $(=0.05)$ は実験的 に決定した ${ }^{9}$ 。変位は制御信号の電圧值（ピエゾ印加電圧）とス キャナの感度から決定した。なお，スキャナの感度は実験前後 で原子像から校正した．図6において，トラッキングコントロー ラの方がより高い振幅の外乱に追従している．図7にトラッキン グコントローラとPIコントローラの制御可能な領域を示寸。同 図(a)，(b)はそれぞれトラッキングコントローラ，PIコントロー ラの結果を示す. 外乱の周波数が $40 \mathrm{~Hz}$ 以下の領域において, 新 しいトラッキングコントローラは格子間隔以上の外乱変位に追 従可能となった。同図(c), (d)は，式 (5) $(k=1 / 2, d=0.25$ $\mathrm{nm}$ ）を用いたシミュレーション結果を示し，それぞれ新しいト ラッキングコントローラ, PIコントローラの結果である．新ト ラッキングコントローラは, シミュレーション結果よりも若干 劣るが，ほぼ似た傾向を示す.

次に原子トラッキング制御の時間安定性（= 熱ドリフト追従 性）を調查した。実験では，探針スキャナの $X$ 方向に $0.1 \mathrm{~nm}, 5$ $\mathrm{Hz}$ の正弦波外乱信号と同時に $75 \mathrm{~dB}$ の音響ノイズ（通常の昼間 の音響レベルより若干高い) を加え, 昼間の環境下で30分間原 子トラッキング制御を行った. 結果の一部（最初の5分間）を図 8に示寸．同図(a)は制御信号の時間変化を示寸．また図中(b),

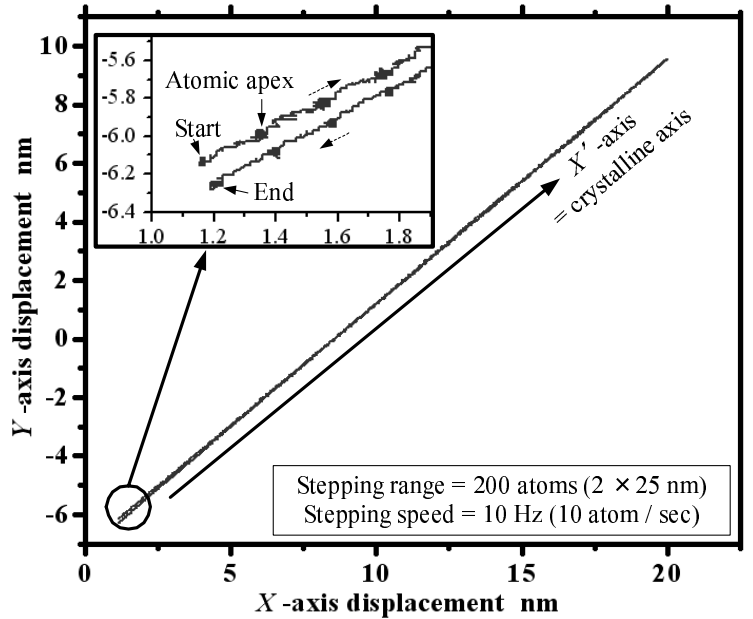

Fig. 11 An experimental result of a stepping control of a STM tip by referring to atomic arrays along the selected direction. The displacement is determined using the sensitivity of the sample scannrer and the $X Y$ controll signal applied to the sample scanner. The crystalline angle and control time were of 40 degrees and $20 \mathrm{sec}$, respectively

(c)は同図(a)のI/II部分の拡大図を示す（a)の右下がりの傾きは, $X$ 方向の熱ドリフトを補償していることを示寸，(b)，(c)は，75 $\mathrm{dB}$ の音響ノイズが存在しても外乱信号に追従しており，同時に 長時間熱ドリフトを補償しながら原子トラッキング制御が達成

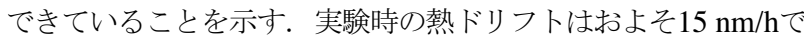
あった．制御中，制御信号に格子間隔相当の急激な変化は見ら れなかった．従って，30分間他の原子一移動することなく熱ド リフトを補償し原子トラッキング制御が達成されたことを確認 した.

以上より，今回新たに提案したトラッキングコントローラを 用いることで，外乱の多い昼間の環境下でも原子トラッキング 制御が安定に動作することが判った。

\section{5. 原子エンコーダの検証}

本節では，安定化を実現したトラッキングコントローラを用 いて, 格子配列に沿ったSTM探針の原子ステップ移動を調べた. 図9は, STMで観察できるグラファイト結晶原子像と原子ステッ プ移動の位置関係を示す，スキャナの駆動軸を $X Y$ 軸，格子配列 に平行な軸を $X^{\prime}$ 軸, それに垂直な軸を $Y$ '軸，また $X$ 軸と $X^{\prime}$ 軸のな 寸角を $\theta$ とする．実験では， $X$ ’方向に原子毎にSTM探針をステッ プ移動させることを目指す. 図10に，図9で示した角度 $\theta$ をパラ メータとするSTM探針の原子ステップ移動の制御ブロック図を 示す。図10において，通常の原子トラッキング制御にステップ 移動のブロック（同図点線で囲まれた部分）を追加した。 なお実 験システムは図5から変更点はない。実験手順を以下に述べる.

（1）STM原子像から，スキャナの $X$ 軸と格子配列 $X^{\prime}$ 軸のなす角 度 $\theta$ を割り出す。

(2) $X Y$ 方向の傾斜信号がゼロになるように制御し, 制御值をサ ンプルスキャナにフィードバック寸ることで原子トラッキ ング制御を行う.

(3) 図10にあるように，1ステップが格子間隔相当となる階段 波の $\cos$ 成分 $(X$ 軸), $\sin$ 成分 $(Y$ 軸) を, $X Y$ 制御信号に 


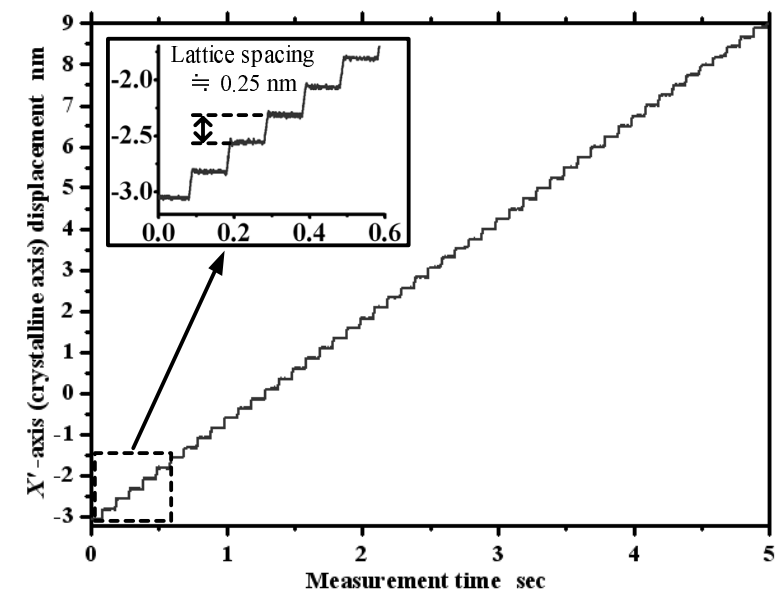

Fig. 12 A time variation of the displacement of the sample scanner in $X^{\prime}$-axis direction (= stepping direction). The displacement is determined using the sensitivity of the sample scannrer and the $X^{\prime}$ controll signal applied to the sample scanner

\section{加算する.}

実験では，熱ドリフト極力抑制をするために，恒温セル内でス キャナ走査を約1日継続してから実験を行った，実験結果を図 11，図12に示寸．図11は制御信号の軌跡を示し，横軸，縦軸は それぞれ $X$ 方向， $Y$ 方向の変位を示寸．このとき格子配列と $X$ 軸 のなす角度 $\theta$ は約 $40^{\circ}$ であった. 10原子 $/ \mathrm{sec}$ のステップ移動を試 みた。制御範囲が約 $25 \mathrm{~nm}$ と狭く, ピエゾの非線形性が小さいと 考えられる為, スキャナの変位は制御信号の電圧值 (ピエゾ印加 電圧）とスキャナの感度の積より決定した．始点と終点でのず れは熱ドリフトによる変位と考えられる．なお，スキャナの感 度は前節と同様に実験前後に原子像から校正した。ここから読 み取った $X Y$ 方向の熱ドリフト速度はそれぞれ $9 \mathrm{~nm} / \mathrm{h}, 29 \mathrm{~nm} / \mathrm{h}$ であった.これはデータ取得前後の原子像から読み取った $X Y$ 方 向の熱ドリフト速度と一致し，正しく元の原子に戻っているこ とを示す．図12は格子配列方向を $X$ 軸とした場合の， $X^{\prime}$ 方向の 制御信号の時間変化を示寸。このとき，XY傾斜信号はほぼゼロ に制御された．1ステップに相当する変位がほぼ格子間隔である $0.25 \mathrm{~nm}^{11)}$ であり, 原子ステップ移動が達成されていることがわ かる. これ以上広い領域での検証には，ピエゾ印加電圧と変位 の間の非線形性が現れるので, 他の変位検出法との比較・検出 が必要と考えている.

\section{6. 結論と今後の課題}

本論文の結論は以下の通りである.
(1) 外乱ノイズの調査を行い，それを基に外乱に対してロバス トなトラッキングコントローラを設計した.

(2) 提案したトラッキングコントローラは, $40 \mathrm{~Hz}$ 以下の領域 なら格子間隔以上の振幅を持つ正弦波状外乱を補償可能に なった．外乱の多い昼間の環境下でも熱ドリフトを補償し ながら最長30分間原子トラッキング制御を達成でき, 昼間 での使用を可能とした.

（3）格子配列方向に沿ってSTM探針の原子ステップ移動を行 い，25 nm（100原子）の範囲を1秒間に10原子の速さで一 往復させた.

これらの成果により, 原子トラッキング制御の高安定化が達 成され, 結晶格子を基準とする原子エンコーダ実現の可能性が 確認された. 原子エンコーダの実用化には, 最大5000原子/sec 程度の移動速度が望まれる. 今後の課題として制御範囲の拡大 と高速化を想定している.

\section{謝辞}

この研究は科学研究費補助金の助成を受けた．ここに謝意を 表す.

\section{参 考 文 献}

1) Chien-ming Wu, John Lawall, and Richard D. Deslattes : Heterodyne Interferometer with Subatomic Periodic Nonlinearity, Appl. Opt. 38, 19 (1999) 4089.

2) A. Bergamin, G. Cavagnero, and G. Mana : Quantized Positioning of X-ray Interferometers, Rev. Sci. Instrum. 68, 1 (1997) 17.

3) G. Binning, H. Rohrer, Ch. Gerber and E. Weibel : Through a Controllable Gap, Appl. Phys. Lett., 40, 2 (1982) 178.

4) H. Kawakatsu and T. Higuchi : A Dual Tunneling-Unit Scanning Tunneling Microscope, J. Vac. Sci. Technol., A8, 1 (1990) 319.

5) M. Aketagawa, K. Takada, K. Kobayashi, N. Takeshima, M. Noro and Y. Nakayama : Length Measurement Using a Regular Crystalline Lattice and a Dual Tunneling Scanning Tunneling Microscope in a Thermo-stabilized Cell, Meas. Sci. Technol., 9,7 (1998) 1076.

6) D.W. Pohl and R. Möller : Tracking Tunneling Microscopy, Rev. Sci. Instrum., 59, 6 (1988) 840.

7) H. Kawakatsu, Y. Hoshi and T. Higuchi : Crystalline Lattice for Metrological Applications and Positioning Control by a Dual Tunneling-unit Scanning Tunneling Microscope, J. Vac. Sci. Technol. B9, 2 (1991) 651.

8）佐久田茂, カマル・ヨゼフ =トーミ: STMを用いた超精密角度センサ （第1報）- 誤差解析とピッチング測定-, 精密工学会誌， 62, 3 (1996) 807.

9) M. Aketagawa, K. Takada, Y. Minao, Y. Oka and J.D. Lee : Tracking and Stepping Control of the Tip Position of a Scanning Tunneling Microscope by Referring to Atomic Points and Arrays on a Regular Crystalline Surface, Rev. Sci. Instrum., 70, 4 (1999) 2053.

10) M. Aketagawa, K. Takada, N. Takeshima, K. Yamada and J.D. Lee : Long Atomic Imaging over a 5- $\mu \mathrm{m}$-Long Region Using an Ultralow Thermally Drifted Dual-Tunneling-Unit Scanning Tunneling Microscope in a Thermostabilized Cell, Rev. Sci. Instrum. 70, 1 (1999) 133.

11) P. Rerkkumsup, M. Aketagawa, K. Takada, T. Watanabe and S. Sadakata : Direct Measurement Instrument for Lattice Spacing on Regular Crystalline Surface Using a Scanning Tunneling Microscope and Laser Interferometry, Rev. Sci. Instrum., 74, 3 (2003) 1205. 